\title{
SANCTIONS AS A LEGAL PHENOMENON IN THE LAW OF UKRAINE AND INTERNATIONAL STANDARDS OF THEIR APPLICATION
}

\author{
Nataliia Iakymchuk, \\ Professor of the Department of Finansical Law, \\ Institute of Law, \\ Taras Shevchenko National University of of Kyiv, \\ Doctor of Juridical Science, Full professor, \\ orcid.org/0000-0002-4848-2323 \\ Scopus ID: https://www.scopus.com/authid/detail.uri?authorId=57215577201 \\ ResearcherID: $A A V-7631-2021$ (https://publons.com/researcher/4614523/nataliia- \\ iakymchuk/) \\ n.yakymchuk@ukr.net
}

\section{Summary}

The article examines the theoretical and practical issues of application of the Law of Ukraine "On Sanctions» of August 14, 2014 and analyzes the existing views on the legal nature of such "legal phenomenon» as sanctions - special economic, financial and other restrictive measures (sanctions) provided by this Law. The article specifies the main issues facing the researchers of the Institute of Sanctions. The purpose of the article is coverage of the state of legal regulation and legal nature of such a phenomenon as sanctions (economic, financial) in the right to Ukraine. In order to achieve this goal, the author used a set of general and special methods that are characteristic of legal science.

The article covers the issue of Ukraine's sovereign right to protection, in particular through the application of economic and other restrictive measures (sanctions) «to protect national interests, national security, sovereignty and territorial integrity of Ukraine, counter terrorist activity, as well as prevention of violations, restoration of violated rights and freedoms and legitimate interests of citizens of Ukraine, society and the state». The range of subjects against which sanctions can be applied has been studied, namely: a) foreign states; b) foreign legal entities; c) legal entities under the control of a foreign legal entity or a non-resident individual, foreigners, stateless persons; d) entities engaged in terrorist activities.

Sanctions are defined as legal measures to respond immediately to violations of various rights, from encroachment on state sovereignty to the commission of a crime of an international nature, which are temporary, which are applied primarily through coercive measures, which are implemented using constitutional, financial, administrative, economic, criminal procedural, executive, economic procedural and other branches of law. The issues of the grounds for application of sanctions, their types and criteria for their delimitation, the term of application of sanctions, as well as the range of authorized entities in the field of their application are covered. The main approaches of scholars to the characterization of sanctions as measures of influence are investigated. It is noted that sanctions are measures of influence different from measures of legal responsibility, which may have a "non-criminal" nature. It is stated that sanctions are measures of influence that are applied, 
albeit in parallel, but in a systematic connection with the criminal prosecution imposed by the state or executed by it as a subject of international cooperation in the fight against crime.

Their application is, firstly, due to the decision at the international or regional level on the application of international economic (financial) sanctions, personal sanctions in the course of criminal prosecution for acts of an international crime. However, Ukraine is obliged to adhere to international standards of the legal mechanism for the application of sanctions at the domestic level, to improve the procedural principles of their application, appeal procedures and amendments to the decision. We consider the participation of the Commissioner for Human Rights in the process of reviewing the decision on the application of sanctions and appealing the decisions necessary. Amendments to the Law of Ukraine "On Sanctions" are proposed in order to establish among the necessary grounds for the application of sanctions to individuals the opening of criminal proceedings against them, and for legal entities - the opening of criminal proceedings against related persons, as well as amendments to the Criminal Procedure Code of Ukraine, as it does not contain provisions on such preliminary measures (securing and stopping) as "sanctions". In addition, in general, the sanctions procedure requires greater transparency, and it is concluded that sanctions can be applied to Ukrainian citizens only if they are suspected of involvement in terrorist activities.

Key words: sanctions, international cooperation in the fight against crime, economic (financial) sanctions, personal sanctions, sectoral sanctions.

\section{Introduction}

With the adoption of the Law of Ukraine «On Sanctions» of August 14, 2014 [1] and the application of its provisions in society, among scholars and legal practitioners there are quite heated discussions about such a concept, «legal phenomenon" as sanctions - special economic, financial and other restrictive measures (hereinafter - sanctions) provided by this Law. The main issues that concern researchers are: 1 ) the legitimacy of sanctions (Volodymyr Yavorsky, [2]); 2) the functions performed by sanctions - they are measures of a preliminary (precautionary) nature, «different from measures of legal responsibility» (Volodymyr Yavorskiy [2]), measures of a political nature - «political instrument» (Darya Sviridova [2]) whether measures of legal responsibility (Bogutskiy Pavlo [3]) or a complex phenomenon, as some of them may belong to different of these groups of coercive measures; 3) legal uncertainty regarding the sphere of legal relations, within which public relations take place regarding the application of economic (financial) sanctions, which is the subject of legal regulation of constitutional, administrative, financial, criminal procedure, economic procedure, civil procedure, execu- tive, international (international) criminal), international legal law, etc; 4) the problem of the separation of the process of imposing economic (financial) sanctions from the criminal process; 5) the legitimacy of the application of economic (financial) sanctions to citizens of Ukraine, primarily in the context of the necessity of guaranteeing by the President of Ukraine the observance of human rights (Maksym Tomochko [2]), as well as to Ukrainian legal entities (Yevhen Zakharov) [2] - the residents; 6) the competence of the subject of decision-making on the application of economic (financial) sanctions, the constitutionality of its legal status as an authorized entity (Lev Semyshotsky [3]); 7) the possibility of litigation or appeal in international commercial arbitration against the application of sanctions or actions (decisions) related to its application (Olena Koch [5]), and many others. However, everyone agrees that the legal structure of the legal nature of economic (financial) sanctions and the mechanism of their application, as well as removal, is very weak. The purpose of this article is not to answer all the questions, but we will focus on the state of legal regulation and the legal nature of such a phenomenon as economic (financial) sanctions in the law of Ukraine. 


\section{The state of legal regulation of the application of sanctions in Ukraine}

Such mechanisms of influence are used in individual states and their unions (in particular Poland, the European Union), and they do not relate to fulfillment or non-fulfillment of bilateral agreements or commercial agreements by their partners, but are conditioned by the necessity of avoiding formed or potential influence on their own national interests, both political and economic.

As of today, the main legislative act of Ukraine regulating the grounds and procedure of application of sanctions is the Law of Ukraine dated August 14, 2014 № 1644-VII [1], which has only 6 articles which define only the basic provisions of application of sanctions, in particular the following.

1. The Law establishes Ukraine's sovereign right to protection - the right to apply special economic and other restrictive measures (hereinafter referred to as the Law - sanctions) «in order to protect national interests, national security, sovereignty and territorial integrity of Ukraine, to counter terrorist activities, as well as to prevent violations, restore violated rights, freedoms and legitimate interests of citizens of Ukraine, society and the state» (Part 1 of Article 1 of the Law);

2. The law sets sanctions in a number of other measures to protect national interests, national security, sovereignty and territorial integrity of Ukraine, its economic independence, rights, freedoms and legitimate interests of citizens of Ukraine, society and the state, in particular, in part 3. 1 of the Law states that the application of sanctions does not exclude the application of other above-mentioned measures. This emphasizes their autonomy as a measure of influence, but there is no detail on which such other measures of protection are mentioned - political, diplomatic, legal, etc.;

3. In Part 2 of Art. 1 of the Law outlines the range of subjects to which sanctions can be applied, namely: a) foreign states; b) foreign legal entities; c) legal entities under the control of a foreign legal entity or a non-resident individual, foreigners, stateless persons; d) entities engaged in terrorist activities.

We will note that citizens of Ukraine to whom sanctions can be applied, proceeding from the content of Part 2 Art. 1 of the Law, may belong exclusively to the last group - entities engaged in terrorist activities. This is important because the Law does not specify the category to which a natural person belongs (citizen, foreigner, stateless person), or the general term «subject» is used (Part 3 of Article 3, Paragraph 1 of Part 1 of Article 3 and Part 3 of Article 5 of the Law) whether there is a clarification «non-resident individual» (Part 3 of Article 3 of the Law);

4. The law defines the grounds for the application of sanctions, in particular: a) «acts of a foreign state, foreign legal or natural person, other entities that create real and/or potential threats to national interests, national security, sovereignty and territorial integrity of Ukraine, promote terrorist activity and/or violate human and civil rights and freedoms, the interests of society and the state, lead to the occupation of territory, expropriation or restriction of property rights, the task of property loss, the creation of obstacles to sustainable economic development, the full exercise by citizens of Ukraine of their rights and freedoms (Paragraph 1, Part 1 of Article 3 of the Law); b) the commission by a foreign state, a foreign legal entity, a legal entity under the control of a foreign legal entity or a non-resident natural person, a foreigner, a stateless person, as well as entities engaged in terrorist activities referred to in paragraph 1 Part 1 of Art. 3 of the Law (mentioned above), in relation to another foreign state, citizens or legal entities of the latter (Part 3 of Article 3 of the Law); c) terrorist activity (Part 2 of Article 1 of the Law); d) resolutions of the General Assembly and the Security Council of the United Nations (paragraph 2, part 1, article 3 of the Law); e) decisions and regulations of the Council of the European Union (paragraph 3, part 1, Article 3 of the Law); f) facts of violations of the Universal Declaration of Human Rights, the Charter of the United Nations (paragraph 4, part 1, article 3 of the Law).

It should be noted that the Law provides for different legal facts - its own unlawful actions, the actions of which cause the application of sanctions, and acts of reaction to such unlawful acts, in particular, international organizations in the form of appropriate decisions.

5. The law defines in Part 1 of the Article 4 of the Law types of sanctions, the list of which is open, as in the Paragraph 25 of Part 1 Article 
4 of the Law it is noted that in addition to the explicitly stated types of sanctions, "other sanctions that comply with the principles of their application established by this Law» may be applied. However, this is a matter of concern, as the question remains open: 1) who determines how «unnamed" sanctions will meet the principles of their application; 2) to what extent the application of «unnamed" sanctions will comply with the principle of legality, which in Part 2 of Art. 3 of the Law is enshrined as a principle of application of sanctions along with such principles as: transparency, objectivity, compliance with the purpose and effectiveness. The principle of legality stipulates that the authorized body acts "only on the basis, within the powers and in the manner provided by the Constitution and laws of Ukraine» (Article 19 of the Constitution of Ukraine) [6].

Most sanctions are aimed at limiting the legal capacity of persons to whom they apply to: 1) the acquisition of property rights; 2 ) free disposal of property («blocking of assets - a temporary restriction of the right of a person to use and dispose of property belonging to him» (Paragraph 1 of Part 1 of Article 4)); 3) freedom of management («restriction of trade operations» (Paragraph 2, Part 1 of Article 4)); 4) freedom of establishment of legal entities ("prohibition to increase the authorized capital of companies, enterprises in which a resident of a foreign state, foreign state, legal a person whose participant is a non-resident or a foreign state owns 10 percent or more of the authorized capital or has an influence on the management of a legal entity or its activities «(Paragraph 16, Part 2 of Article 4) [1], etc. The imposition of such sanctions stipulates that state bodies are obliged to monitor operations and, if detected, to stop (block) them (active activity), or in the case of a person subject to sanctions, not to take actions prescribed by law (passive activity).

However, a separate group of sanctions is aimed directly at establishing additional responsibilities of state bodies, providing for their active action, in particular: 1) implementation of additional control actions, in particular: introduction of additional measures in the field of environmental, sanitary, phytosanitary and veterinary control (Paragraph 17 Part 1 of Article 4 [1]); 2) cancellation of permits issued by them, decisions in particular: cancellation of visas for residents of foreign states, application of other bans on entry into the territory of Ukraine (Paragraph 21, Part 1 of Article 4 [1]); cancellation of official visits, meetings, negotiations on the conclusion of contracts or agreements (Paragraph 23, Part 1 of Article 4); deprivation of state awards of Ukraine, other forms of celebration; 3) establishment of certain prohibitions (restrictions) for state bodies in relations with persons subject to sanctions, in particular such as: refusal to issue visas to residents of foreign states, application of other prohibitions on entry into the territory of Ukraine (paragraph 21, part 1 of Art. 4 [1]).

Some sanctions established by this Law are financial in nature - those that directly affect the financial and legal relations, in particular they include such as: 1) a ban on issuing permits, licenses of the National Bank of Ukraine to invest in foreign countries, placement of currency values on accounts and deposits in the territory of a foreign state (Paragraph 13, Part 1 of Article 4 [1]); 2) termination of issuance of permits, licenses for import to Ukraine from a foreign state or export from Ukraine of currency values and restriction of cash issuance on payment cards issued by residents of a foreign state (paragraph 13, part 1 of Article 4 [1]); 3) prohibition of registration by the National Bank of Ukraine of a participant in an international payment system, the payment organization of which is a resident of a foreign state (paragraph 13, part 1 of Article 4 [1]); 4) «prohibition of public and defense procurement of goods, works and services from legal entities-residents of a foreign state of state ownership and legal entities, the share of the authorized capital of which is owned by a foreign state, as well as public and defense procurement from other business entities, selling goods, works, services originating from a foreign state to which sanctions have been applied in accordance with this Law» (paragraph 10, part 1 of Article 4 [1]).

In addition, sanctions are divided into two groups: 1 «sectoral sanctions» (Part 2 of Article 5 of the Law [1]) - provided for in paragraphs 1-5, 13-5, 17-19, 24-1, 25 Part 1 of Art. 4 of the Law of Ukraine «On Sanctions" (Part 2 of Article 5 of the Law [1]); 2) «personal sanctions» - provided for in paragraphs 1-21, 23-24, 25 Part 1 of Art. 4 
of the Law of Ukraine "On Sanctions» (Part 3 of Article 5 of the Law [1]).

6. Contains provisions on the duration of sanctions, but this issue is not clearly regulated. Part 5 of Art. 5 of the Law of Ukraine «On Sanctions" states that «a decision on the application of sanctions must contain the term of their application, except in cases of application of sanctions that lead to termination of rights and other sanctions that cannot be applied temporarily». Thus, if some sanctions are in the nature of temporary restrictions and play the role of measures to stop the violation or prevent the violation of public interests or legal rights, others - restrictive measures of a permanent nature, forcing the subjects to whom they apply to be restricted in personal or property rights.

6) determines the authorized entities in the field of sanctions, which include:

a) subjects of initiation of application - the Verkhovna Rada of Ukraine, the President of Ukraine, the Cabinet of Ministers of Ukraine, the National Bank of Ukraine, the Security Service of Ukraine (paragraph 1 of Article 5 of the Law [1]). They make proposals for the application of lifting and amending sanctions. We will note that among the specified only Security Service of Ukraine belongs to law enforcement agencies [7]. In this case, only the President of Ukraine may initiate the termination of international agreements, the consent to the binding nature of which was given by the Verkhovna Rada of Ukraine, as a sanction provided by this Law (Part 4 of Article 5 of the Law [1]);

b) the subject of consideration (Part 1 of Article 5 of the Law [1]) and decision-making on the application, repeal or amendment of sanctions (Parts 2, 3 of Article 5 of the Law [1]) - the National Security and Defense Council of Ukraine (hereinafter - the National Security and Defense Council), except for such a sanction as «termination of international agreements, the binding nature of which was approved by the Verkhovna Rada of Ukraine». Regarding this moment of the Law, lawyers have the most questions and complaints: 1) according to the Constitution of Ukraine, the National Security and Defense Council does not belong to the executive branch of state, but is a "coordinating body for national security and defense under the President of Ukraine», which "coordinates and controls the activities of executive bodies in national security and defense» (Art. 107 of the Constitution of Ukraine [6]), headed by the President of Ukraine (paragraph 18 of Article 106, Article 107 of the Constitution of Ukraine [6]) and "the competence and functions of the National Security and Defense Council of Ukraine are determined by law». In particular, Lev Semyshotsky quite reasonably raises the question of the constitutionality of the powers of the National Security and Defense Council in the field of sanctions, given the lack of constitutional powers of the President of Ukraine and the National Security and Defense Council of the judiciary, quasi-judicial body or a body regulating property or economic relations" [4];

c) the subject of enforcement of the decision on the application of personal sanctions, which takes effect from the date of issuance of its Decree [8] and is binding - the President of Ukraine (Part 3 of Article 5 of the Law [1]);

d) the subject of enforcement of the decision on the application of sectoral sanctions, which enters into force upon its approval by a resolution of the Verkhovna Rada of Ukraine the President of Ukraine (Part 3 of Article 5 of the Law [1]);

e) the subject of consideration and decision-making on the application of such a sanction as "termination of international agreements approved by the Verkhovna Rada of Ukraine», which comes into force from the moment of adoption of the resolution - the Verkhovna Rada of Ukraine (Part 4 of Art. 5 of the Law [1]);

f) the subject of approval of the decision on the application of sectoral sanctions (approval takes the form of a resolution [9] within 48 hours from the date of the decree of the President of Ukraine) - the Verkhovna Rada of Ukraine (Part 2 of Article 5 of the Law [1]) as the Parliament of Ukraine.

\section{The legal nature of sanctions}

As of today, the views of scholars and practitioners on the legal nature of sanctions are divided. Therefore, sanctions are considered as: measures of influence different from measures of legal responsibility, the application of which, as Volodymyr Yavorsky notes, «does not abolish the obligation of the state to conduct a criminal investigation and prosecute citizens of Ukraine 
if there are appropriate grounds" [2]. Under this approach, sanctions can be considered as measures of a preliminary (security) nature (stopping the offense and ensuring prosecution). The researcher believes that «a sufficient basis for the application of sanctions is a reasonable suspicion of committing illegal activities, which arises on the basis of information, which often can not be evidence in criminal proceedings. The second distinguishing feature is their temporary nature, and the third - «reactivity» - prompt, rapid application, which is due to the need to avoid the negative consequences of certain activities, the occurrence of greater social damage and so on. Thus, we can note that sanctions under such an approach refer to measures of suspension and measures to ensure the application of measures of legal responsibility, if the fact of committing an offense (crime or misdemeanor) is proved» [2];

Sanctions may be «non-criminal». Thus, Mykola Khavronyuk notes regarding the legal nature of sanctions that it is, with one exception, not criminal, but administrative-legal, given that: 1) sanctions in the law are abbreviated as «special economic and other restrictive measures" and based on from the name of these measures and other provisions of the law, it is not a penalty, but a restriction of economic and other related activities that promote terrorism, other encroachments on national interests, national security, sovereignty and territorial integrity of Ukraine; their introduction had «rather, a political goal - to emphasize the readiness of the Ukrainian state to respond to hostile actions, taking into account the peculiarities of hybrid warfare»; 2) in contrast to criminal liability measures, "special economic and other restrictive measures» provided by the Law «On Sanctions» do not consist in depriving a person of liberty, property or other constitutional rights and freedoms; 3) «restrictive measures, which are listed in Article 4 of the Law of Ukraine» On Sanctions", were contained in the laws of Ukraine long before 2014 under the same or similar name and applied to violators of the law by the relevant authorities» [10]. It should be agreed with M. Havronyuk that the grounds for the application of these restrictions are different from those provided by the Law "On Sanctions", and the listed laws do not contain references to the grounds for the application of sanctions provided by this law. This means that they cannot be applied directly on the basis of the decision of the National Security and Defense Council and the decree of the President, for their application it is necessary to make additions to the relevant laws, which would indicate that the relevant restrictions may be applied to the implementation of the Law "On Sanctions». While these additions are not available, the application of the relevant restrictions and prohibitions may be declared unfounded by the court» [10]. However, we also note that primarily the basis for the application of «non-criminal» sanctions, which include sanctions as special economic and other restrictive measures, based on the provisions of Art. 3 of the Law of Ukraine "On Sanctions" are resolutions of the General Assembly and the Security Council of the United Nations and decisions and regulations of the Council of the European Union, which they adopt by virtue of international treaties. Thus, under Chapter VII of the UN Charter, the Security Council may apply coercive measures to maintain or restore international peace and security. According to Art. 41 sanctions include a wide range of non-military coercive options. The Security Council imposes sanctions to ensure peaceful transitions, prevent unconstitutional change, deter terrorism, protect human rights and promote the nuclear non-proliferation regime. There are currently 14 sanctions regimes in place to support political conflict resolution, nuclear non-proliferation and the fight against terrorism. Each sanctions regime is chaired by a specific sanctions committee headed by a non-permanent member of the Security Council. In 2005 World Summit Declaration, the General Assembly called on the Security Council to ensure, with the support of the Secretary-General, the adoption of fair and clear procedures for the imposition and lifting of sanctions [11].

Measures of influence are applied in parallel, but in a systematic connection with the criminal prosecution initiated by the state or carried out by it as a subject of international cooperation in the fight against crime. Therefore, sanctions are enforced both by the country that introduced them and through the mechanisms of international cooperation - and other states and international organizations. Such an approach 
is justified when it comes to such grounds for imposing sanctions as a decision of a resolution of the General Assembly and the United Nations Security Council (Paragraph 2, Part 1, Article 3 of the Law [1]) and decisions and regulations of the Council of the European Union (Paragraph 3, Part 1, Article 3 of the Law [1]), or on sanctions imposed by the decision of the National Security and Defense Council, as a result of which the relevant international organizations are appealed to initiate the inclusion of certain persons in the sanctions lists, which takes place in accordance with with organized crime, money laundering and corruption. Thus, the European Union once applied sanctions against Ukrainian officials precisely on the grounds that criminal proceedings have been opened against them in Ukraine and an investigation is under way. Accordingly, the EU Court did not overturn the decision to impose sanctions on those persons subject to criminal proceedings, and on others who provided documents certifying the absence of any criminal proceedings against them in the Ukrainian legal system - canceled.

\section{International standards for the application of sanctions at the state level}

Apparently, for the first time the freezing of bank accounts as a type of financial sanction was introduced by UN Security Council Resolution 841 (1993) in connection with the need to resolve the political and economic situation in Haiti [12, p. 2-3]. However, today, according to Yulia Malysheva, the regimes of financial (economic) sanctions of the UN Security Council include a wide range of coercive measures aimed at restricting international capital movements - «freezing foreign assets of the government, enterprises and institutions of the offending state, restricting access to financial markets, termination of financial assistance, as well as blocking the bank accounts of individuals and legal entities specified in the sanctions resolution» [13, p. 89]

The tactical purpose of freezing the assets of coercive measures is to deprive their listed owners of the opportunity to use cash, other financial assets or economic resources to carry out illegal activities, such as the acquisition of weapons or the development of their own production, support for terrorism. or the imple- mentation of other measures in connection with which sanctions are imposed [13, p. 90]

Thus, in the course of international cooperation in the fight against terrorism, the UN Security Council established a committee authorized to prepare and update in due time the lists of individuals and legal entities associated with Osama bin Laden and the Taliban [14]. Resolution 1333 (2000) called on all States to prosecute individuals and legal entities, and to apply appropriate penalties, to provide information to the Committee for the exercise of its powers, as well as information on the measures taken by them, and to freeze funds and other financial assets Committee of individuals and legal entities, including funds and assets of Al-Qaeda organizations, as well as funds received or raised through property owned or directly or indirectly controlled by them [14]. The Sanctions Committee was established on the basis of UN Security Council Resolution 1267 (1999) [15] and has worked effectively.

According to Yulia Malysheva, «the legal shortcomings of the procedure introduced by the resolutions were the deprivation of persons included in the list, the opportunity to learn about the decision, the grounds taken into account by the Committee when listing them, and the inability to provide objections, explanations and evidence of non-involvement in terrorist organizations» [13]. In addition, the established mechanism did not provide for a procedure for appealing the decision to include in the lists, including to an independent competent body authorized to verify the validity of the decision, as well as procedures for its cancellation.

The European Union, in turn, has introduced rules of EU law that provide for the freezing of assets and other economic resources of individuals and organizations whose names are on the UN list [16]. The European Union has expressed the view that sanctions may be imposed on foreign governments of third countries or non-state legal and natural persons, including terrorist movements, groups or persons involved in terrorist activities [17]. These measures affected a large number of people. The UN Special Rapporteur on Human Rights and Terrorism stated that the list regime «has resulted in hundreds of individuals or bodies having their property frozen and other fundamental rights 
restricted» [18]. However, despite the inconsistency of the listing procedure with generally accepted international norms on the protection of the right to a fair trial, the courts of a number of European countries refused to examine the applicants' arguments for unjustified inclusion in the sanctions list under UN Security Council Resolutions 94 (1999) and 1373 (2001), citing lack of jurisdiction. In this case, the courts, as a rule, relied on the provisions of Article 103 of the UN Charter, which establishes the priority of obligations of member states under the UN Charter, over obligations under any other international agreement [13, p. 94]. With regard to the mechanism for imposing sanctions, it should be noted that Member States may at any time provide the Committee with the names of individuals and legal entities for inclusion in the sanctions list in accordance with UNSCR 1844 (2008) [19].

Over time, a structure (central office) was established within the UN Sanctions Committee, which was responsible for reviewing the complaints of persons included in the lists. UNSCR 1735 (2006) introduced a more thorough and complete preparation of materials for inclusion in the lists, as well as the obligation to notify a person or organization of inclusion in the sanctions list and as a supplement to this notification a copy of the decision stating the circumstances of the case and informing about the consequences of sanctions [20 p. 4-5], as well as procedures for exclusion from the list [13, p. 95]. In addition, the Office of the UN Security Council Ombudsman was established separately in accordance with Resolution 1904 (2009) (the powers of which have been extended by a number of other documents), and its mandate is enshrined in UN Security Council Resolution 2368 (2017) [21]. It should be noted that as a result of consideration of applications for exclusion from the sanctions lists, a significant number of applicants received a positive result $[22$, p. 5]. Decisions of the EU Council are more relevant for Ukraine, such as: 1) EU Council Decision 2014/145 / CFSP of 17 March 2014 (in connection with actions that undermine or threaten the territorial integrity, sovereignty and independence of Ukraine (provides for so-called personal sanctions)); 2) EU Council Decision 2014/386 / CFSP dated 23.06.2014 (sanctions in connection with the illegal annexation of the Autonomous Republic of Crimea and the city of Sevastopol); 3) EU Council Decision 2014/512 / CFSP of 31.07.2014 (sanctions in connection with the actions of the Russian Federation to destabilize the situation in Ukraine (so-called sectoral sanctions)); 4) EU Council Decision 2014/119 / CFSP of 05.03.2014 (EU sanctions against former high-ranking officials of Ukraine and their immediate entourage) [23] and others, from 1 July and 19 December 2016, 28 June and 21 December 2017, 05 July and 21 December 2018, 27 June and 19 December 2019 year, June 29 and December 17, 2020 and July 12, 2021 [24].

Thus, sanctions are imposed both at th*e level of international organizations and by states themselves, which may be the basis for states to appeal to the relevant international states and through interstate cooperation, and it is the mechanism of sanctions imposed by states that is of most concern today.

In his study, Thomas Hammamberg points out that in 2007 Council of Europe parliamentarian Dick Marty prepared a report criticizing exclusion procedures and restrictions on remedies for individuals or organizations on those lists [16]. Maksym Tymochko also draws attention to the fact that «international sanctions should not be considered to be automatically enforceable» and to the fact that the Resolutions of the Parliamentary Assembly of the Council of Europe of 2008 refer to certain standards that sanctions must meet. It states that they «must meet certain criteria, including legal certainty, providing a fundamental guarantee of the process, informing the person subject to sanctions that he or she is subject to certain indirect charges, such as terrorism, and being able to challenge such measures» [2].

Thus, PACE Resolution 1597 (2008) states that «targeted sanctions (such as restrictions on the movement and freezing of bank accounts) have a direct impact on personal human rights, such as personal freedom and protection of property. It is not yet clear and debatable whether such sanctions are criminal, administrative or civil in nature, and their implementation, in accordance with the European Convention on $\mathrm{Hu}-$ man Rights and the International Convention on Civil and Political Rights, must take into account minimum standards of procedural protection and legal certainty». Paragraph 5 of the same resolution enshrines the following procedural and substantive standards to be guaranteed to 
ensure the credibility and effectiveness of targeted sanctions: «5.1). The minimum procedural standards in accordance with the rule of law are the following rights: 5.1.1. be duly informed and fully informed of the charges against the person and of the decisions taken, as well as of the reasons for such a decision; 5.1.2. have the fundamental right to be heard and to have the right to defend themselves against these charges; 5.1.3. have the right to review a decision affecting personal rights as soon as possible by an independent and impartial body with a view to amending or revoking it; 5.1.4. receive compensation for wrongful violation of rights; 5.2) Minimum substantive standards require a clear definition of the reasons for the imposition of sanctions and relevant evidence» [25]. In addition, PACE Resolution 1597 (2008) emphasizes that the «blacklist» procedure should be limited in time. It is unacceptable that a person remains blacklisted for years, while the investigating authorities, after a long investigation, have not found any evidence against him «(paragraph 5.3), and it is noted that" procedural and substantive standards that are now their applied by the UN Security Council and the Council of the EU, with the exception of some recent improvements, do not in any way meet the minimum standards set out above and violate fundamental principles of human rights and the rule of law «(paragraph 6) [25].

In turn, PACE Resolution 2087 (2016) states that: 1) «any sanctions against persons must meet the requirements of legal certainty and be accompanied by appropriate procedural guarantees» (paragraph 10); 2) «all restrictive measures must comply with the requirements of international law, the principles of good governance and respect for the law».

The Committee of Ministers of the Council of Europe reaffirmed that «it is important that these sanctions be accompanied by the necessary procedural guarantees» [26]. There have been repeated appeals to the courts to protect those who believe that the sanctions were applicable to them both unreasonably and unlawfully.

On August 3, 2008, the EU Court of Justice ruled on the controversy over the jurisdiction of the sanctions list in the case of Yassin Kadi and the Barakaat International Foundation. The Court found that, under European law, the provisions contained in resolution 1267 (1999) vio- lated procedural and human rights by depriving the persons to whom they applied of the opportunity to obtain information on their inclusion in the sanctions lists and, therefore, which do not provide for any mechanisms for appealing the decisions of the Committee [27].

Thus, the Court of Justice of Luxembourg found that the regulations of the European Council, on the basis of which their funds and other economic resources were frozen, violated their fundamental rights, in particular their right to property and their right to a judicial review of these decisions. The Court recognized that the importance of the global fight against terrorism could not be underestimated and that all member states of the Council of Europe had a full duty to combat terrorism and had a positive obligation to protect the lives of their citizens [Ottoman case], but stated that «human rights is a condition for the legality of Community acts and that measures incompatible with respect for human rights are not acceptable in the Community». A court ruling in the Qadi and Al Barakaat case set a two-month deadline for the EU to correct shortcomings in the listing process. At the same time, the legislation of the European Community is based on basic human rights. The measures taken to uphold peace and security must comply with these rights, as stated in the European Convention for the Protection of Human Rights and the EU Charter on fundamental Rights [16].

Pavlo Bogutsky notes that "the unity of two requirements, which actually form the legal content of sanctions, is decisive for national and international legal orders: 1) compliance of sanctions with the provisions in the first case of national legislation, in the second case with international legal acts and principles of international law; 2) observance of legal procedure or legal procedural form of application of sanctions». And also emphasizes that procedure of application of sanctions for protection of national (economic, political, state, etc.) interests by the state often cannot have judicial character, $<\ldots>$ however the efficiency and urgency of such sanctions in no way deny the principles of the rule of law and legality, but on the contrary affirm the implementation of these principles on the basis of protection of national interests, achieving the necessary security level for sustainable development of society [3]. 
On the important provision of Part 2 of Art. 6 of the Law of Ukraine "On Sanctions", which states that «laws and other regulations of Ukraine operate in part that does not contradict this Law» notes Lev Semyshotsky, who believes that this «crosses the whole array of rights and guarantees to protect a person from arbitrary actions on the part of his own state» [4].

Yulia Malysheva expressed a fairly common position among researchers of international law, noting that «individuals and legal entities under international law, although endowed with certain powers and rights, but, unlike states and international organizations, can not carry international legal liability, except for criminal (for individuals), for the most serious crimes against humanity" [13 p. 36], and therefore we believe that the sanctions applied to them within the mechanism of international legal cooperation in the fight against crime should be applied as an integral part of the mechanism of criminal prosecution of individuals and legal entities.

\section{Conclusions}

Sanctions are legal measures to respond immediately to violations of various rights, from encroachment on state sovereignty to the commission of a crime of an international nature, which are temporary, which are applied primarily through coercive measures, which are implemented using constitutional, financial, administrative, economic, criminal procedural, executive, economic procedural and other branches of law. The grounds for applying the type of sanctions under Ukrainian law depend on the category of the entity to which they apply and the mechanism of execution of the decision - on the type of sanction and the scope of its application (in accordance with domestic or international law). Their application is, firstly, due to the adoption at the international or regional level of decisions on the application of international economic (financial) sanctions, personal sanctions in the course of criminal prosecution for acts of an international crime (crimes of an international nature), which prompted the adoption of international documents referred to in paragraphs 2 and 3 of Art. 3 of the Law of Ukraine "On Sanctions", the implementation of which Ukraine carries out by virtue of its obligations as a subject of international law, and secondly, due to the need to protect sovereignty and its own public interests, and respond to crimes, including including actions that undermine the national security, sovereignty and territorial integrity of Ukraine, or are related to terrorism and the application of sanctions at the domestic level, as well as to initiate their application at the international and regional levels.

However, Ukraine is obliged to adhere to international standards of the legal mechanism for the application of sanctions at the domestic level, to improve the procedural principles of their application, appeal procedures and amendments to the decision. We consider the participation of the Commissioner for Human Rights in the process of reviewing the decision on the application of sanctions and appealing the decision necessary. The Law of Ukraine "On Sanctions» should also be amended in order to establish among the necessary grounds for the application of sanctions to individuals the opening of criminal proceedings against them, and for legal entities - the opening of criminal proceedings against related persons. According to Article 2, which defines the legal basis for the application of sanctions, the modest word «laws» should be replaced by «Criminal Procedure Code of Ukraine and other laws», and part 2 of Article 6 should be stated in the wording «Laws and other regulations of Ukraine operate in part, which does not contradict the Constitution of Ukraine, the Criminal Procedure Code of Ukraine, this Law". Accordingly, the Criminal Procedure Code of Ukraine needs to be amended, as it does not contain provisions on such preliminary measures (securing and stopping) as «sanctions».

In addition, the sanctions procedure in general needs to be more transparent. In practice, we see that sanctions are often applied to citizens of Ukraine, while the Decisions of the National Security and Defense Council of Ukraine, enacted by decrees of the President of Ukraine do not explicitly state the grounds for applying appropriate sanctions, while the content of part 2 of Article 1 of the Law of Ukraine "On Sanctions» they can be applied to them only in case of suspicion of their participation in terrorist activities.

\section{Bibliography:}

1. Про санкиії (2014): Закон України № 1644-VII. URL: https://zakon.rada.gov.ua/laws/show/1644-18\#Text

2. Чиста політика, правовий механізм чи просто вендетта? (2021). Українська Гельсінська спілка з прав 
людини. URL: https://helsinki.org.ua/articles/chystapolityka-pravovyy-mekhanizm-chy-prosto-vendetta/

3. Богуцький, П. (2021). Про санкції: санкційний механізм і національна безпека. Наукова думка. URL: https:// ukrainepravo.com/scientific-thought/naukova-dumka/prosanktsiyi-sanktsiynyy-mekhanizm-i-natsionalna-bezpeka/

4. Семишоцький, Л. (2021). Верховенство санкцій. Закон@Бізнес, 16 (1522). URL: https://zib.com.ua/ ua/147253-chi_ne_zagrozhuyut_nacionalniy_bezpeci_ metodi_ii_zahistu.html

5. Коч, О. (2020). Визнати не можна виконати: статус «під санкціями» та міжнародний комерційний арбітраж. Юрист\&Закон, 40. URL: https://uz.ligazakon. ua/ua/magazine_article/EA014237

6. Конституція України (1996). URL: https://zakon.rada. gov.ua/laws/show/254к/96-вр\#Text

7. Про державний захист працівників суду і правоохоронних органів (1993): Закон України No 3781-XII. URL: https://zakon.rada.gov.ua/laws/show/3781-12\#Text

8. Про рішення Ради національної безпеки і оборони України від 15 квітня 2021 року «Про застосування персональних спеціальних економічних та інших обмежувальних заходів (санкцій)» (2021): Указ Президента України No 169. URL: https://www.president. gov.ua/documents/1692021-38729

9. Про затвердження рішення Ради національної безпеки і оборони України від 1 лютого 2021 року «Про застосування секторальних спеціальних економічних та інших обмежувальних заходів (санкцій) до Республіки Нікарагуа» (2021): Постанова Верховної Ради України No 1167-IX. URL: https://zakon.rada. gov.ua/laws/show/1167-20\#Text

10. Хавронюк, М. (2021). Про «санкції» як спеціальні обмежувальні заходи: регламентація і ризики застосування. URL: https://rpr.org.ua/news/pro-sanktsii-iakspetsial-ni-obmezhuval-ni-zakhody-rehlamentatsiiai-ryzyky-zastosuvannia/

11. Санкции Совета Безопасности. Совет Безопасности $\mathrm{OOH}$. URL: https://www.un.org/securitycouncil/ru/ sanctions/information

12. Resolution 841 (1993), adopted by the Security Council at its 3238th meeting, on 16 June 1993. Haiti. URL: https://undocs.org/S/RES/841(1993)

13. Малишева, Ю.В.(2016). Цілеспрямовані санкції та їх застосування Радою Безпеки ООН. Київ: Інститут держави і права ім. В.M. Корецького? 253 с. URL: http://idpnan. org.ua/files/malisheva-yu.v-tsilespryamovani-sanktsiyita-yih-zastosuvannya-radoyu-bezpeki-oon-_d_pdf

14. Резолюция 1333 (2000) Совета Безопасности $\mathrm{OOH}$. URL: https://undocs.org/pdf?symbol=ru/S/ RES/1333(2000)
15. Resolution 1267 (1999) Adopted by the Security Council at its 4051st meeting on 15 October 1999. URL: https://documents-dds-ny.un.org/doc/UNDOC/ GEN/N99/300/44/PDF/N9930044.pdf?OpenElement

16. Hammarberg, T. (2000). Arbitrary procedures for terrorist black-listing must now be changed.URL: https://www.coe. int/ru/web/commissioner/viewpoints/asset_publisher/ xZ32OPEoxOkq/content/arbitrary-procedures-forterrorist-black-listing-must-now-be-chang-1?_101 INSTANCE_xZ320PEoxOkq_languageld=en_GB

17. Sanctions Policy. European Union. External Action. URL: http://eeas.europa.eu/cfsp/sanctions/index_en.htm

18. Statement by Martin Scheinin Special rapporteur on the promotion and protection of human rights and fundamental freedoms while countering terrorism (2008) $63^{\text {rd }}$ session of the General Assembly Third Committee, 22 October 2008, New York.

19. Procedures for Listing. United Nations Security Council. URL: https://www.un.org/securitycouncil/ sanctions/751/materials/procedures-for-listing

20. Resolution 1735 (2006) Adopted by the Security Council at its 5609th meeting, on 22 December 2006. Threats to international peace and security caused by terrorist acts. URL: https://undocs.org/ru/S/RES/1735(2006)

21. Ombudsperson to the ISIL (Da'esh) and Al-Qaida Sanctions Committee. United Nations Security Council. URL: https://www.un.org/securitycouncil/ru/ ombudsperson

22. Subsidiary organs of the United Nations Security council. Fact sheets. 2021. United Nations Security Council. Working Groups, 5 p. URL: https://www.un.org/ securitycouncil/sites/www.un.org.securitycouncil/ files/subsidiary_organs_factsheets.pdf

23. Санкції ЄC (2021). Представництво України при Європейському Союзі. URL: https://ukraine-eu. mfa.gov.ua/posolstvo/spivpracya-ukrayina-yes-usferi-zovnishnoyi-politiki-i-bezpeki/sankciyi-yesu-vidpovid-na-agresiyu-rosiyi-ta-proti-kolishnihvisokoposadovciv-ukrayini

24. UC Sanctions Map. Russia. URL: https://www. sanctionsmap.eu/\#/main

25. Резолюція ПАРЄ 1597 (2008). Чорні списки Ради безпеки OOH та Європейського Союзу. URL: http:// w1.c1.rada.gov.ua/pls/mpz2/docs/751_1597_CHorni spysky_rezoljutsija.htm

26. Parliamentary Assembly Recommendation 1824 on «United Nations Security Council and European Union blacklists» (2008). URL: https://www.legislationline. org/documents/id/9066

27. Judgment of the Court (Grand Chamber) on joint cases C-402/05 and 415./05 Jasin Abdullah Kadi and Al 
Barakaat International Foundation v. Council of the European Union and the Commission of the European Communities of 3 September 2008. European Court Report. (2008). URL: http://eur-lex.europa.eu/legalcontent/EN/TXT/?uri=CELEX:62005CJ0402

28. Санкции Совета Безопасности. Совет Безопасности $\mathrm{OOH}$. URL: https://www.un.org/securitycouncil/ru/ sanctions/information

\section{References:}

1. Pro sanktsiyi: Zakon Ukrayiny [About Sanctions: Law of Ukraine] (2014) № 1644-VII.Available from: https://zakon. rada.gov.ua/laws/show/1644-18\#Text [in Ukrainian].

2. Chysta polityka, pravovyy mekhanizm chy prosto vendetta? [Pure politics, legal mechanism or just vendetta?] (2021). Ukrayins'ka Hel'sins'ka spilka z prav lyudyny [Ukrainian Helsinki Human Rights Union]. Available from: https://helsinki.org.ua/articles/chystapolityka-pravovyy-mekhanizm-chy-prosto-vendetta/ [in Ukrainian].

3. Bogutskiy, P. (2021). Pro sanktsiyi: sanktsiynyy mekhanizm i natsional'na bezpeka [About sanctions: sanction mechanism and national security] (2021). Naukova dumka [Scientific thought]. Available from: https://ukrainepravo.com/scientific-thought/naukovadumka/pro-sanktsiyi-sanktsiynyy-mekhanizm-inatsionalna-bezpeka/ [in Ukrainian].

4. Semishotsky L. (2021). Verkhovenstvo sanktsiy [The rule of sanctions].Zakon@Biznes [Law@business], 16 (1522). Available from: https://zib.com.ua/ua/147253chi_ne_zagrozhuyut_nacionalniy_bezpeci_metodi_ii_ zahistu.html [in Ukrainian].

5. Koch 0. (2020). Vyznaty ne mozhna vykonaty: status «pid sanktsiyamy» ta mizhnarodnyy komertsiynyy arbitrazh [Recognize can not be performed: Status «under sanctions» and international commercial arbitration] (2020). Yuryst\&Zakon [Lawyer \& Law], 40. Available from: https://uz.ligazakon.ua/ua/magazine_ article/EA014237 [in Ukrainian].

6. Konstytutsiya Ukrayiny [The Constitution of Ukraine] (1996). Available from: https://zakon.rada.gov.ua/ laws/show/254k/96-вp\#Text [in Ukrainian]

7. Pro derzhavnyy zakhyst pratsivnykiv sudu i pravookhoronnykh orhaniv [About state protection of court and law enforcement officers] (1993): Zakon Ukrayiny [Law of Ukraine] No 3781-XII. Available from: https://zakon. rada.gov.ua/laws/show/3781-12\#Text [in Ukrainian].

8. Pro rishennya Rady natsional'noyi bezpeky i oborony Ukrayiny vid 15 kvitnya 2021 roku «Pro zastosuvannya personal'nykh spetsial'nykh ekonomichnykh ta inshykh obmezhuval'nykh zakhodiv (sanktsiy)» [About the decision of the National Security and Defense Council of Ukraine dated April 15, 2021 «On the application of personal special economic and other restrictive measures (sanctions)»] (2021): Ukaz Prezydenta Ukrayiny [Decree of the President of Ukraine] No 169. Available from: https://www.president.gov.ua/ documents/1692021-38729 [in Ukrainian].

9. Pro zatverdzhennya rishennya Rady natsional'noyi bezpeky i oborony Ukrayiny vid 1 lyutoho 2021 roku «Pro zastosuvannya sektoral'nykh spetsial'nykh ekonomichnykh ta inshykh obmezhuval'nykh zakhodiv (sanktsiy) do Respubliky Nikarahua» [On approval of the decision of the National Securityand Defense Council of Ukraine dated February 1,2021 «On the application of sectoral special economic and other restrictive measures (sanctions) to the Republic of Nicaragua»] (2021): Postanova Verkhovnoyi Rady Ukrayiny [Resolution of the Verkhovna Rada of Ukraine] No 1167-IX. Available from: https://zakon.rada.gov.ua/laws/show/1167-20\# Text [in Ukrainian].

10. Khavronyuk M. (2021). Pro «sanktsiyi» yak spetsial'ni obmezhuval'ni zakhody: rehlamentatsiya i ryzyky zastosuvannya [About «sanctions» as special restrictive measures: regulation and application risks]. Available from: https://rpr.org.ua/news/pro-sanktsii-iak-spetsial -ni-obmezhuval-ni-zakhody-rehlamentatsiia-i-ryzykyzastosuvannia/ [in Ukrainian].

11. Sanktsii Soveta Bezopasnosti [Sanctions of the UN Security Council]. Sovet Bezopasnosti OON [UN Security Council]. Available from: https://www.un.org/ securitycouncil/ru/sanctions/information [in Russian].

12. Resolution 841 (1993) Adopted by the Security Council at its 3238th meeting, on 16 June 1993. Haiti. Available from: https://undocs.org/S/RES/841(1993) [in English].

13. Malysheva, YU. V. (2016). Tsilespryamovani sanktsiyi ta yikh zastosuvannya Radoyu Bezpeky OON [Purposeful sanctions and their use of the UN Security Council]. Kyyiv: Instytut derzhavy i prava im. V.M. Korets'koho. 253 p. Available from: http://idpnan.org.ua/files/ malisheva-yu.v.-tsilespryamovani-sanktsiyi-ta-yihzastosuvannya-radoyu-bezpeki-oon-_d_pdf [in Ukrainian].

14. Rezolyutsiya 1333 (2000) Soveta Bezopasnosti OON [UN Security Council resolution 1333 (2000)]. Available from: https://undocs.org/pdf?symbol=ru/S/ RES/1333(2000) [in Russian].

15. Resolution 1267 (1999) Adopted by the Security Council at its 4051st meeting on 15 October 1999. Available from: https://documents-dds-ny.un.org/doc/UNDOC/GEN/ N99/300/44/PDF/N9930044.pdf?OpenElement [in English].

16. Hammarberg T. (2000). Arbitrary procedures for terrorist black-listing must now be changed. Available 
from: https://www.coe.int/ru/web/commissioner/ viewpoints/asset_publisher/xZ320PEoxOkq/content/ arbitrary-procedures-for-terrorist-black-listing-mustnow-be-chang-1?_101_INSTANCE_xZ320PEoxOkq_ languageld=en_GB [in English].

17. Sanctions Policy. European Union. External Action. Available from: http://eeas.europa.eu/cfsp/sanctions/ index_en.htm [in English].

18. Statement by Martin Scheinin Special rapporteur on the promotion and protection of human rights and fundamental freedoms while countering terrorism $63^{\text {rd }}$ session of the General Assembly Third Committee, 22 October 2008, New York. [in English].

19. Procedures for Listing. United Nations Security Council. Available from: https://www.un.org/securitycouncil/sanctions/751/materials/procedures-for-listing [in English].

20. Resolution 1735 (2006) Adopted by the Security Council at its 5609th meeting, on 22 December 2006. Threats to international peace and security caused by terrorist acts. Available from: https://undocs.org/ru/S/ RES/1735(2006) [in English].

21. Ombudsperson to the ISIL (Da'esh) and Al-Qaida Sanctions Committee. United Nations Security Council. Available from: https://www.un.org/securitycouncil/ ru/ombudsperson [in English].

22. Subsidiary organs of the United Nations Security council. Fact sheets. 2021. United Nations Security Council. Working Groups. 5 p.Available from:https://www.un.org/ securitycouncil/sites/www.un.org.securitycouncil/files/ subsidiary_organs_factsheets.pdf [in English].
23. Sanktsiyi YES [EU sanctions] (2021). Predstavnytstvo Ukrayiny pry Yevropeys'komu Soyuzi [Representation of Ukraine with the European Union.]. Available from: https://ukraine-eu.mfa.gov.ua/posolstvo/spivpracyaukrayina-yes-u-sferi-zovnishnoyi-politiki-i-bezpeki/ sankciyi-yes-u-vidpovid-na-agresiyu-rosiyi-ta-protikolishnih-visokoposadovciv-ukrayini [in Ukrainian].

24. UC Sanctions Map. Russia. Available from: https://www. sanctionsmap.eu/\#/main [in English].

25. Rezolyutsiya PARYE 1597 [Resolution PACE 1597] (2008). Chorni spysky Rady bezpeky OON ta Yevropeys'koho Soyuzu [Black Lists of the UN Security Council and the European Union.]. Available from: http://w1.c1.rada.gov.ua/pls/mpz2/docs/751_1597_ CHorni_spysky_rezoljutsija.htm [in Ukrainian].

26. Parliamentary Assembly Recommendation 1824 on «United Nations Security Council and European Union blacklists» (2008). Available from: https://www. legislationline.org/documents/id/9066 [in English].

27. Judgment of the Court (Grand Chamber) on joint cases C-402/05 and 415./05 Jasin Abdullah Kadi and Al Barakaat International Foundation v. Council of the European Union and the Commission of the European Communities of 3 September 2008. European Court Report. (2008). URL: http://eur-lex.europa.eu/legal-content/EN/TXT/? uri=CELEX:62005CJ0402 [in English].

28. Sanktsii Soveta Bezopasnosti [Sanctions of the Security Council.]. Sovet Bezopasnosti OON [UN Security Council.]. URL: https://www.un.org/securitycouncil/ru/ sanctions/information [in Russian].

\title{
САНКЦІЇ ЯК ПРАВОВИЙ ФЕНОМЕН В ПРАВІ УКРАЇНИ ТА МІЖНАРОДНІ СТАНДАРТИ ЇХ ЗАСТОСУВАННЯ
}

\author{
Наталія Якимчук, \\ професор кафедри фінансового права Інституту права Київького національного \\ університету імені Тараса Шевченка \\ доктор юридичних наук, професор, \\ orcid.org/0000-0002-4848-2323
}

Scopus ID: https://www.scopus.com/authid/detail.uri?authorId=57215577201 ResearcherID: AAV-7631-2021 (https://publons.com/researcher/4614523/nataliia-iakymchuk/) iakymchuk.n@gmail.com

\section{Анотація}

В статті досліджено теоретичні та практичні питання застосування Закону України «Про санкції» від 14 серпня 2014 року та проаналізовані існуючі погляди на правову природу «правового феномену» санкцій - спе- 
ціальних економічних, фінансових та інших обмежувальних заходів (санкціі), передбачені зазначеним Законом. В статті зазначено основні питання, що постають перед дослідниками інституту санкцій. Метою статті $\epsilon$ висвітлення стану правового регулювання та правової природи такого явища як санкції (економічні, фінансові) в праві Україні. Для досягнення цієі мети було застосовано комплекс загальнонаукових і спеціальних методів, що є характерними для правової науки.

В статті висвітлено питання суверенного права України на захист зокрема шляхом застосуванння економічних та інших обмежувальних заходів (санкцій) «з метою захисту національних інтересів, національної безпеки, суверенітету і територіальної цілісності України, протидії терористичній діяльності, а також запобігання порушенню, відновлення порушених прав, свобод та законних інтересів громадян України, суспільства та держави». Досліджено коло субєєктів стосовно яких може бути застосовано санкції, а це: а) іноземні держави; б) іноземні юридичні особи; в) юридичні особи, які знаходяться під контролем іноземної юридичної особи чи фізичної особи-нерезидента, іноземців, осіб без громадянства; г) субєєкти, які здійснюють терористичну діяльність.

Санкції визначено як правові заходи негайного реагування на порушення права різного роду, від посягання на державний суверенітет до вчинення злочину міжнародного характеру, що мають тимчасовий характер, застосування яких відбувається передусім шляхом здійснення заходів примусу, які реалізуються зі застосуванням норм передусім конституційного, фінансового, адміністративного, господарського, кримінального поцесуального, виконавчого, господарського процесуального та інших галузей права. Висвітлено питання підстав застосування санкцій, їх види та критерії їх розмежування, строку застосування санкцій, а також кола уповноважених субєєктів у сфері ї застосування. Досліджено основні підходи вчених до характеристики санкцій як заходів впливу. Відмічено, що санкції $\epsilon$ заходами впливу відмінними від заходів юридичної відповідальності, що можуть мати “некримінальний” характер. Зазначено, що санкції є заходами впливу, які застосовуються хоч і паралельно, але у системному звязку із кримінальним переслідуванням, що запроваджуються державою або виконуються нею як суб'єктом міжнародного співробітництва у боротьбі зі злочинністю.

Ïх застосування, по-перше, обумовлено прийняттям на міжнародному чи регіональному рівнях рішення про застосування міжнародних економічних (фінансових) санкцій, персональних санкцій в ході кримінального переслідування за вчинення діянь, що мають характер міжнародного злочину (злочину міжнародного характеру). Однак, при цьому Україна зобов'язана дотримуватися міжнародних стандартів правового механізму застосування санкцій на внутрішньодержавному рівні, вдосконалити процесуальні засади їх застосування, процедури оскарження та внесення змін до рішення. Необхідною вважамо участь Уповноваженого з прав людини в процесі розгляду рішення про застосування санкцій та оскарження прийнятих рішень. Запропонновано зміни до Закону України «Про санкції» з метою закріплення серед необхідних підстав застосування санкцій до фізичних осіб відкриття щодо них кримінального провадження, а щодо юридичних осіб - відкриття кримінального провадження щодо пов'язаних з ними осіб, а також зміни до Кримінального процесуального кодексу України, оскільки в ньому відсутні положнення про такі заходи попереднього характеру (забезпечення та зупинення), як «санкції». Окрім цього загалом процедура накладення санкцій потребує більшої прозорості, а також зроблено висновок, що до громадян України можуть бути застосовані санкції виключно в разі підозри ї участі в терористичній діяльності.

Ключові слова: санкції, міжнародне співробіництво у боротьбі зі злочинністю, економічні (фінансові) санкції, персонвальні санкції, секторальні санкції. 